ISSN: 2146-3042

DOI: $10.25095 /$ mufad.673676

\title{
Spor Kulüplerinde Finansal Raporlama Ve Türkiye Muhasebe Standartlarına(TMS) Göre Özellikli İşlemlere İlişkin Örnek Yevmiye Kayıtları*
}

\author{
Adnan SEVIM* \\ Samet BÜLBÜL**
}

\section{$\ddot{O Z E T}$}

Günümüzde spor kulüplerinde meydana gelen değişme ve gelişmeler, kulüplerin ulaştı̆̆l ekonomik büyüklük, spor ekonomisi kavramını ortaya çıkarmıştır. Spor kulüplerinin ticari bir yapıya bürünerek yüksek teknoloji yatırımları yapması, büyük bütçelere sahip olması, gelir ve giderlerinin önemli tutarlara ulaşması ise finansal raporlama sistemi ihtiyacını doğurmuştur. Söz konusu sistemin bir gereği olarak, spor kulüplerinin uluslararası camiada doğruluk, şeffaflık, hesap verebilirlik anlamında yaptı̆̆ tüm işlemlerin, uluslararası muhasebe standartlarına uygun hale gelmesi ise spor kulüplerinin daha kurumsal bir yapıya kavuşmasına imkan hazırlamıştır. Bu çalışmada, spor kulüplerindeki finansal raporlama sistemi ve bu sistemdeki muhasebeleştirme işlemleri, Türkiye Muhasebe Standartları açısından ele alınmış ve örnekler geliştirilmiştir.

Anahtar Kelimeler: Finansal Raporlama, UEFA, Finansal Fair Play, Muhasebe Standartlarl

JEL Sinıflandirması: G32, M41, M48.

Financial Reporting In Sports Clubs And Samples Journal Entries Related To Featured Transactions According To Turkish Accounting Standards (TMS)

\section{ABSTRACT}

Today, the changes and developments in sports clubs, the economic size of clubs, sports economy has revealed the concept. The fact that sports clubs under take a high technology investment by having a commercial structure, having big budgets and reaching significant amounts of income and expenses has created the need for financial reporting system. As a requirement of the system in question, the fact that sports clubs perform in the international community in terms of accuracy, transparency and accountability has made it possible for sports clubs to have a more corporate structure. In this study, the financial reporting system in sports clubs and accounting processes in the system, in terms of Turkey Accounting Standards discussed and examples were developed.

Keywords: Financial Reporting, UEFA Financial Fair Play, Accounting Standarts

Jel Classification: G32, M41, M48

* Makale GönderimTarihi: 15.05.2019, Makale Kabul Tarihi: 11.07.2019, Makale Türü: Araştırma makalesi

* Doç. Dr., Anadolu Üniversitesi, İktisadi ve İdari Bilimler Fakültesi, asevim@anadolu.edu.tr,Araştırma

Makalesi, Orcid ID: 0000-0002-0864-3719

** Anadolu Üniversitesi, Sosyal Bilimler Enstitüsü, bulbulsamet@yahoo.com, Orcid ID: 0000-0003-2795-4608 


\section{GİRiş}

Spor faaliyetlerinin ekonomik olarak bir sektöre dönüşmesi ve büyük bütçeli bir endüstri kolu haline gelmesi, spor kulüplerinin faaliyetlerinin daha sistematik yürütülmesini gerektirmiştir. Başlangıçta dernek olarak kurulan spor kulüpleri, ilerleyen yıllarda, büyük kitlelere ulaşmasının da etkisiyle şirketleşme yoluna gitmiş ve bu durum halka açılmayı da beraberinde getirmiştir. Halka açılan ve payları borsada işlem gören spor kulüplerinde ise sermaye piyasasının kuralları gereği finansal raporlama anlamında önemli gelişmeler meydana gelmiştir. $\mathrm{Bu}$ gelişmelerden en önemlisi ise Uluslararası Finansal Raporlama Standartlarının ülkemizde uygulanması neticesinde, spor kulüplerinin de bu kurallara uyma zorunluluğunun ortaya çıkmasıdır. Ayrıca Avrupa Futbol Federasyonları Birliği(UEFA) tarafindan ortaya konulan UEFA mali kriterlerininbu raporlama standartların öngörmesikonunun önemini daha belirgin hale getirmiş ve kulüp faaliyetlerinin ve işlemlerinin söz konusu kriter ve standartlara uygun hale gelmesini gerektirmiştir. Kulüplerdeki bütün bu işlemlerin muhasebe standartlarına uygun raporlanması ise hem kurumsal yönetimi geliştirmiş hem şeffaflık ve hesap verilebilirliği artırmış hem de ulusal ve uluslararası anlamda karşılaştırılabilir raporlara olanak sağ lamıştır.

Ülkemizde spor kulüplerindeki finansal raporlama hakkında yapılan çalışmalara bakıldı̆̆ında konunun kapsamlı şekilde ele alınmadığı görülmektedir. Konunun spor kulüpleriyle ilgili olması ve sporun günlük hayatta karşılık bulması nedeniyle de gazetelerde ve internet üzerindeki haber sitelerinde oldukça farklı değerlendirmeler mevcuttur. Ancak, akademik yazın açısından bakıldığında, yapılan çalışmalar genellikle UEFA Finansal Fair Play kriterleri ve bu kriterlerin uygulanması ile ilgili olup konunun muhasebeleştirme boyutu yeteri kadar incelenmemiştir. Ayrıca, spor kulüplerinin kamuoyuna açıkladıkları finansal raporlardaki açıklayıcı dipnot bilgilerinin eksikliği, akademik çalışmalara yeteri kadar katkı sunmamaktadır. Konu ile ilgili literatür çalışması yapıldığında aşağıdaki çalışmaların olduğu görülmektedir:

Aydın vd. (2007), "Spor Kulüplerinin Halka Açılmasının Türkiye'de Uygulanan Modeller Açısından İncelenmesi" adlı çalışmada halka açılma süreci ve uygulanan modelleri incelemişlerdir.

Devecioğlu (2012), "Türkiye'de Spor Kulüplerinin Şirketleşmeye Yönelimlerinin Değerlendirilmesi” adlı çalş̧masında kulüplerin şirketleşme sürecini ve sonuçlarını değerlendirmiştir.

Soysal (2010), "Kulüp ile Profesyonel Futbolcu Arasındaki Sözleşmeler ve Sözleşmelerden Doğan İhtilaflarda Yargı Yeri” adlı çalışmasında sözleşmelerden kaynaklı işlemleri hukuki bakış açısıyla değerlendirmiş ve sözleşme hukukunu incelemiştir.

Sultanoğlu (2008), Hisseleri Halka Arz Edilen Türk Futbol Kulüplerinin Mali Tablolarının Türkiye Muhasebe Standartları Çerçevesinde İncelenmesi” adlı yayımlanmamış yüksek lisans tezinde konuyu muhasebe standartları çerçevesinde ele almış ancak yevmiye kayıtlarıyla ilgili muhasebeleştirme örneklere yer vermemiştir. 
Yazarkan (2016), "Futbolcu Transfer/Bonservis Ücretlerinin TMS 38 Maddi Olmayan Duran Varlıklar Standardına Uygun Olarak Muhasebeleştirilmesi: Trabzonspor Örneği” adlı çalışmasında sadece futbolcu transfer/bonservis ücretleri konusunu ele almıştır.

Zeren ve Gümüş (2013), “Türk ve Yabancı Futbol Takımlarının Borsa Performansları Üzerine Bir Uygulama” adlı çalışmada halka açık futbol kulüplerinin borsa performanslarını değerlendirmiştir.

$\mathrm{Bu}$ çalışmada, spor kulüplerindeki finansal raporlama ve bu konuya ilişkin muhasebeleştirme örnekleri, Kamu Gözetimi Kurumu tarafından 2019 y1lı içerisinde yayınlananve yakında yürürlüğe girmesi beklenen Finansal Raporlama Standartlarına Uygun Hesap Planı Taslağıçerçevesinde yapılmıştır. Özellikli işlemlere yönelik muhasebeleştirme işlemlerinin, söz konusu hesap planına uygun olarak yapılmasıyla literatüre katkı sağlamak hedeflenmektedir.

\section{SPOR KULÜPLERININ KURULUŞLARINA ILIŞKIN YASAL DÜZENLEMELER}

Türkiye'deki spor kulüpleri, 5253 sayılı Dernekler Kanunu'nun “Gençlik ve Spor Kulüpleri” başlıklı 14. maddesinde düzenlenmiş olup söz konusu derneklerden başvurmaları halinde; spor faaliyetine yönelik olanların spor kulübü olarak faaliyetlerini yapabilecekleri ifade edilmiştir. Aynı kanunun 1.maddesinde ise kanunun amacı ifade edilirken "...dernekler, dernek şube veya temsilcilikleri, federasyonlar, konfederasyonlar ve yabancl dernekler ile merkezleri yurt dışında bulunan dernek ve vakıf dışındaki kâr amacı gütmeyen kuruluşların Türkiye'deki şube veya temsilciliklerinin yasak ve izne tâbi faaliyetlerini, yükümlülüklerini, denetimlerini ve uygulanacak cezalar ile derneklere ilişkin diğer hususları düzenlemektir." hükmü yer almaktadır. Bu anlamda, spor kulüplerinin dernek kütüklerine kayıt ve tescil edilmesi ile başlayan süreç, kulüplerin görev ve yetkilerinin belirlenmesi, usul ve esaslarının tanımlanması ve denetimi ile ilgili yürürlüğe konulan tebliğ ve yönetmeliklerle düzenlenmiştir.

Kulüplerin profesyonel takımlar oluşturabilmesi, sporun geliştirilerek profesyonelliğin sağlanabilmesi ancak yasal düzenlemelere uyumla birlikte mümkündür. Bu kapsamda, spor alanında faaliyet gösteren derneklerin, aynı kanunun 27.maddesinde ifade edilen "Spor Kulüpleri Tescil Taahhütnamesi” gereği spor faaliyetlerinin amacına dönük olarak yapacakları her bir işlem ilgili kanunlar çerçevesinde olmalı ve kuruluş ve yapılanma amacına uygun olmalıdır. Spor kulüplerinin dernek olarak kurulmaları, özünde kar amacı güden kuruluş olmadıklarından kaynaklanmaktadır. Ayrıca ticari faaliyet yapamayan spor kulüpleri, sportif faaliyetler yaparak varlıklarını sürdürmüşler ve günümüze kadar gelmişlerdir. Bunun yanında, spor kulüplerinin aslında dernek olarak kurulmuş olmaları onlara (özellikle Katma Değer Vergisi Kanunu ve Kurumlar Vergisi Kanunu) vergisel konularda önemliavantajları sağlamakta ve spor teşviklerinden/muafiyetlerinden faydalanmalarına olanak tanımaktadır. Spor kulüplerininprofesyonelleşmesi, dernek statüsünde iken gerçekleştiremedikleri ticari faaliyetlerini hayata geçirebilmesinde ve gelir kaynaklarından daha fazla yararlanmasında önemli biradım olmuştur. Bu gelişme ise spor kulüplerinin şirketleşme yoluyla Türk Ticaret Kanunu hükümlerine göre Sportif A.Ş. kurulma sürecini hızlandırmıştır. Bu konu ilerleyen başlıkta ele alınacaktır. 


\section{SPOR KULÜPLERININ ŞİRKETLEŞMESİ VE HALKA ARZI}

Başlangıçta dernekler kanununa tabi olarak yönetilen spor kulüplerinin belirli bir zaman sonrasında, gelir ve giderlerinin kontrol edilmesi, yönetimde etkinliğin sağlanması ve ticari faaliyetlerinin çeşitlenmesiyle birlikte daha fazla gelir elde etmek istemeleri şirketleşme sürecini hızlandıran en önemli faktörlerdendir. Spor kulüplerinin kuruluşlarından günümüze yapmış oldukları faaliyetleri ele aldığımızda, değişen ve gelişen spor ekonomisi hem ticari hem sportif gelir kaynaklarından daha fazla yararlanmalarını gerekli kılmıştır. Bunların yanında, bütçelerin büyümesi, harcama kalemlerinin ve maliyetlerin artması, kurumsallaşmaya duyulan ihtiyaç, kulübe daha ekonomik fon temininin yapılmak istenmesi de bu süreci desteklemiştir(Aydın vd.,2007:46). Bahsedilen faktörler, spor kulüplerinin daha güçlü bir yapıya kavuşması, daha şeffaf ve hesap verilebilir hale gelmesinin önünü açmış ve sermaye piyasası kanunlarına uyumla birlikte halka açılma sürecini başlatmıştır. Dolayısıyla, spor kulüplerindeki şirketleşme sürecinin halka arz ile devam etmesi; ticari ve sportif gelirleri artırma ve yapılacak büyük yatırımları hayata geçirme konusundaki süreci tamamlayan önemli bir gelişmedir.

Spor kulüplerinin bütçelerinin büyümesi ve bunun getirdiği yönetimsel zorluklar, kurumsal yönetime duyulan ihtiyacı daha belirgin hale getirmiştir(Devecioğlu,2012:94). Bu durum fon kaynaklarının çeşitlendirilerek daha fazla kaynak temini ve UEFA mali kriterlerine uyumla birlikte dikkate alındığında kurumsal yönetim ilkelerinin uygulanmasını zorunlu kılmaktadır. Ayrıca artan rekabetçi ortamda, maliyetlerin kontrolü, vergisel avantajlardan en iyi faydalanma ve finansman ihtiyacının artması kulüpleri halka açılmaya yönelten nedenler arasında yerini almıştır(Zeren ve Gümüş,2013:88). Bu sebeplerle, spor kulüpleri uzun vadeli kaynak bulma, kredi imkanlarından faydalanma ve yeterli kaynaklarla birlikte profesyonel yönetim anlayışına da kavuşmak için halka arzı önemli bir araç olarak görmüşlerdir.

Ülkemizde spor kulüplerinin halka açılma sürecini başlatan futbol kulüpleri, bu süreci 2002 yılında başlatmışlardır. Futbol kulüplerinin finansal anlamda karşılaştıkları güçlükler, mevcut riskleri azaltma çabaları ve Avrupa'daki büyük kulüplerin şirketleşme ve halka açılma sürecinin önceden gerçekleştirmiş olması bu süreci hızlandıran faktörler arasındadır. Halka açılma sürecinde, Sermaye Piyasası Kurulu(SPK) tarafından07.02.2002 tarihinde yayınlanan 9/181 sayılı Haftalık Bülten“Futbol Kulüpleri'nin Halka Açılması için Belirlenen İlave Kriterler" hakkındaki kararını ortaya koymaktadır. Söz konusu kriterlere bakıldığında en çok önem arz eden konunun şeffaflık ve hesap verebilirlik olduğu görülmektedir. Her ne kadar ülkemizdeki büyük futbol kulüpleri halka açık olsalar da dernek yapılanması hala devam ettirilmektedir. $\mathrm{Bu}$ durum ise spor kulüplerin şirketleşme sürecinin başarıyla devam ettirilmesinde birtakım engelleri ortaya çıkarmaktadır(Akşar,2005:59). Mevcut durumu ele aldığımızda ortaya çıkan bu durum, dernekler kanununa göre yönetilen kulüplerinin muhasebe kayıtlarının şeffaf, doğru ve güvenilir şekilde yapılmasına da engel teşkil etmektedir. Dolayısıyla, spor kulüplerinin halka açılma sürecinin, onların mevcut muhasebe sistemlerini etkilemesi ve faaliyetlerinin kamuya hesap verme zorunluluğunu gerektirmesi, kulübün profesyonel yönetim anlayışına sahip olmasına katkı sağlayarak önemli bir eksikliği gidermiş olacaktır. 


\section{KULÜPLERIN VE SPORTIF ŞİRKETLERIN EKONOMIK YAPISI}

Spor kulüplerinin şirketleşme ve halka açılma süreci, gerçekleştirdikleri faaliyetleri çeşitlendirmiş ve ilave gelir kaynaklarının oluşmasına olanak hazırlamıştır. Profesyonel anlamda sportif faaliyetlerin yapıldığı kulüplerde iktisadi faaliyetlerin çeşitlenmesi, gelirlerde olduğu gibi giderlerde de yeni kalemlerin oluşmasına neden olmuştur. Her ne kadar dernek yapısı devam etse de sportif faaliyetlerin devam ettiği ve ticari faaliyetlerin yürütüldüğü tüzel kişilik adı altındaki şirketlerde ortaya çıkan gelir ve giderler ile bunların şirket bilançosundaki etkisi aşağıdaki başlıklarda incelenecektir.

\subsection{Spor Kulüplerinin Gelir ve Giderleri}

Spor ekonomisinin büyümesi ve spor faaliyetlerinin yanında yeni gelir kaynaklarının oluşması kulüplerin gelirlerinde önemli artışlar meydana getirmiştir. Kulüplerin iktisadi anlamda yeni işletmeler kurması, profesyonel anlamda sportif faaliyetlerinin dişında ticari olarak daha fazla gelir elde etmeye başlaması mal ve hizmet üretimi ve satışını artırmıştır. Bu kapsamda spor kulüplerinin sportif ve sportif dışı en temel gelir kaynaklarını ele aldığımızda ilk karşımıza çıkan karşılaşma hasılatları/bilet satış gelirleridir. Bu gelirler ulusal ve uluslararası karşılaşmalarda kulüpler tarafında elde edilen bilet satışlarını kapsamaktadır. Bunun yanında; yayın hakkı(havuz) gelirleri, ürün reklam gelirleri, sponsor gelirleri, lisanslı ticari ürünlerinisim hakkı gelirleri, şampiyonlar ligindeki ve diğer turnuvalardaki gelirler, sporcu transferi ve kiralamaları, üyelik aidat gelirleri, bağış ve yardımlar, stadyum gelirleri, stat tesis ve kira gelirleri, menkul kıymet gelirleri, tazminat, cezalar ve ödüller, UEFA gelirleri şeklinde sıralanabilir.

Spor kulüplerinin giderlerine baktığımızda en önemli gider kalemleri sporcu transferi ve ücret ödemeleridir. Bunun yanında sportif faaliyetlerin etkin ve verimli sürdürülebilmesi ve profesyonel anlamda çalışmaların devam ettirilmesi için de katlanılması gereken giderler mevcuttur. Bunlar; lisans sözleşmesi kapsamında yapılan ödemeler, stadyum kiralama giderleri, antrenör/teknik adam giderleri, garanti ödemeleri, menajerlik giderleri, bonservis ödemeleri, maç başına yapılan ödemeler, genel yönetim giderleri, kamp giderleri,sosyal tesis giderleri, ulaşım giderleri ve UEFA giderleri şeklinde sıralanabilir.

\subsection{Spor Kulüplerinin Aktif ve Pasif Yapısı}

Halka açık spor kulüplerinin Kamuoyu Aydınlatma Platformu'ndayayınlanan mali tablo ve dipnotlarına bakıldığında aktif ve pasif yapısını gösteren bilgiler görülmektedir.Hâlihazırda4 büyük spor kulübünün halka açık olduğundan hareketle; buradaki bilgiler incelendiğinde, aktif yapısında göze çarpan ilk husus, en büyük hesap kalemininİlişkili Taraflardan Alacaklar hesabında olduğudur. Hesabın dipnot bilgi ve açıklamaları incelendiğinde ise, kulübün bağlı olduğu dernek ve bağlı ortaklıklardan alacakların büyük miktarlara ulaştığı anlaşılmaktadır. Bu kapsamda, her kulüpteki varlık yapısında alacakların önemli bir yerinin olduğu ve bu alacakların da dernek ve bağlı ortaklıklardan olduğu görülmektedir. İlişkili taraf işlemlerinin yoğunluğu ve içeriğinin yayınlanan mali tablo dipnotlarında sadece tutar olarak açıklanıp detay bilgisine yer verilmemesi şeffaflık ve hesap verebilirlik anlamında bazı sakıncalar doğurmaktadır. TMS 24 İlişkili Taraf Açıklamaları standardı gereği; ilişkili tarafla yapılan işlemlerin tutarı, varsa taahhütler ve bunların açıklamaları, teminatlar olup olmadığı, varsa teminat karşılıkları, 
verilen ya da alınan garantilerin durumu, alacakların şüpheli halde olup olmadığ 1 ve dönem içinde ilişkili taraflarla yapılan işlemlerde değersiz alacakların tutarı gibi ifade edebileceğimiz açıklamaların yer almaması mali tablo dipnotları açısından da önemli eksiklikler barındırmaktadır. Bunun yanında duran varlıklar hesap grubu incelendiğinde, en yüksek tutarın sporcu sözleşme ve lisans bedellerinin izlendiği maddi olmayan duran varlıklar grubundaki "Haklar" hesabında olduğu dipnot bilgilerinden anlaşılmaktadır.

Spor kulüplerinin bilançosunun pasif kısmına bakıldığında, en dikkat çeken konu, her dört kulübün de yükümlülüklerinin, bir diğer ifadeyle borçlarının oldukça fazla olmasıdır. Mevcut muhasebe politikaları ve uygulamaları gereği ve sermayenin korunması ilkesinden hareketle kulüplerin içinde bulunduğu bu durum işlemenin sürekliliği ilkesine zarar vermektedir. Örneğin, Galatasaray Sportif A.Ş.'nin31 Mayıs 2018 tarihli konsolide finansal tabloları bağımsız denetim raporundaki açıklamalara bakıldığında, dönen varlıkların kısa vadeli yükümlülüklerini karşılamakta yetersiz kaldığı ve net özkaynakların negatif olduğu sonucu çıkmaktadır. Bu durum ise, işletmedeki sürekliliğin devamında önemli şüpheler oluşturabilecek ciddi bir belirsizliği ifade etmektedir. Ayrıca bu konu, Türk Ticaret Kanunu'nun376.maddesinde yer alan, şirketin borca batıklık durumuna işaret ettiğinden,kulüp yönetim kurulunun tedbirler almasını gerektiren bir konu olarak karşımıza çıkmaktadır.

Kulüplerin gelir ve giderleri ile aktif ve pasif yapıları bir arada ele alındığında, gelir ve giderlerin oldukça çeşitliolduğu,hem ticari hem de sportif anlamda birçok işlemin yapıldığ görülmektedir. Ancak aktif ve pasif yapısındaki zayıflık ve özellikle yüksek borçluluk düzeyi spor kulüplerini oldukça zor durumda bırakmaktadır. Öncesinde dernek yapısıyla birliktedevam eden şirketleşme süreci ve sonrasında halka arz edilme, spor kulübüne yeni fonlar bulmada önemli bir faktör olmuştur ancak kamuoyuna açıklanan bilgilerden hareketle, halka arzın sonrasında kulüp borçları azalmamış ve faaliyetler yüksek borçlanma ile devam ettirilmiştir. Bütün bu gelişmeler ise UEFA Finansal FairPlay(FFP) mali kriterlerinin uygulanmasını gerekli hale getirmiş ve mali kriterlere uymayan kulüplere ciddi yaptırım ve cezalar gelmeye başlamıştır. Bu konu ise ilerleyen başlıkta ele alınacaktır.

\section{SPOR KULÜPLERİNDEKİ FINANSAL RAPORLAMA SİSTEMI VE UEFA FFP KRITERLERI}

Ülkemizdeki kulüplerkuruluş yapılarına göre ele alındığındadernek ve sportif şirket olmak üzere ikili bir varlık yapısı görülmektedir. Spor kulüplerinin bu ikili yapıyı sürdürmeleri finansal raporlama ve muhasebe sistemi kurma gibi konularda önemli eksiklikleri beraberinde getirmektedir. UEFA mali kriterleri ise, rekabetin oldukça yoğunlaştığı günümüz spor dünyasında bu eksiklikleri ortadan kaldırmak, sportif başarıları daha artırmak ve kulüplerin mali yapılarında ortaya çıkan sorunları gidermek için belirli kriterler getirmiştir. Bu konular aşağıdaki başlıklarda ele alınacaktır.

\subsection{Spor Kulüplerindeki Finansal Raporlama Sistemi}

Spor kulüpleri, dernek yapısı içerisindeki muhasebe sisteminde genel olarak gelir ve giderlerin kayıt altına almakta, politika ve prosedürlerini de bu doğrultuda oluşturmaktadır. Dernekler kar amacını güden kurumlar olmadığından, ticari faaliyetlerini tam anlamıyla yapamamakta sadece sportif faaliyetlerle ilgilenmektedirler. Bu durum ise, derneklerin kendi içerisinde İşletme Hesabı Esası'na göre defterlerini tutmasını gerektirmektedir. Anonim şirket 
haline gelen kulüplerde ise Türk Ticaret Kanunu'daki Bilanço Esası'na göre ticari defterlerin tutulması ve kayıtların yapılması gerekmektedir. Aynı şekilde, dernek yapısında faaliyetlerini devam ettiren kulüplerde belirli bir dönemde elde edilen gelir ve giderler raporlanmalı ve sunulmalıdır.

İşletme Hesabı Esası'na göre tutulan bu defterler neticesinde dönem sonlarında 5253 Sayılı Dernekler Kanunu'nun 11.maddesi gereği “İşletme Hesabı Tablosu” düzenlenmelidir. $\mathrm{Bu}$ tablo, sadece gelir ve giderleri göstermesi açısından oldukça basit bir yapıda olup bilgi kullanıcılarının ihtiyaçlarına yönelik yeterli düzeyde ve miktarda içeriğe sahip değildir. Bunun yanında, şirketleşen ve halka arz edilen spor kulüplerinde ise Bilanço Esası'na göre defterler tutulmakta ve bunlar da hesap döneminin sonunda kamuoyu ile paylaşılmaktadır. Söz konusu kayıtlar ise 1 Sıra No'lu Muhasebe Sistemi Uygulama Genel Tebliği esaslarına göre yapılmalı, mali tablolar hazırlanmalı ve ilgili konularda Sermaye Piyasası Kurulu düzenlemelerine tabi olunmaktadır. Dolayısıyla spor kulüplerinin dernek yapısını sürdürüp sürdürmediği, şirketleşip halka açılıp açılmadığı gibi konular finansal raporlama sistemini doğrudan etkilemektedir. Faaliyet raporlarında yer alan bilgilerin doğru, güvenilir ve şeffaf olması, düzenli bir şekilde raporlanması, finansal bilgi kullanıcılarının ihtiyaçlarını karşılaması, uygulanan ilke, usul ve esasların tam açıklanması finansal raporlama sisteminin etkin olup olmadığının da bir göstergesi konumundadır.

\subsection{UEFA Finansal FairPlay(FFP) Kriterleri}

Spor kulüplerindeki finansal güçlüklerin önlenmesi, risklerin azaltılması, mali dengelerin korunması, sürdürülebilirliğin sağlanması amacıyla UEFA İcra Kurulu tarafından 2009 yılında ortaya konulan FFP kriterleri, finansal bilgi kullanıcılarına doğru ve güvenilir bilgiler sunmayı hedefleyen kuralları bütününü ifade etmektedir(UEFA,2012). Bu anlamda UEFA mali kriterleri, spor kulüplerinin finansal yapısının güçlendirilmesini, mali disiplinin sağlanmasını, varlık ve kaynaklardaki denetimin sağlanmasını ve kurumsallaşma çabalarının artırılmasını amaçlamaktadır. Bu amaçlar doğrultusunda UEFA kulüpler için dört başlıkta toplanabilecek kriterler belirlemiştir. Bunlar(TKYD,2009;UEFA,2012:114):

1. Sportif Kriterler(Genç Oyuncular),

2. Altyap1 Kriterleri(Seyir Ortam1, Stadyum Kriterleri)

3. Personel ve Yönetim Kriterleri(Profesyonelleşme),

4. Hukuki Kriterler(Ortak Yasal Altyapi)

5. Mali Kriterlerdir(Ücret Oranları, Şeffaflık, Sağlıkıı Mali Yapı)

UEFA FFP kriterleri, finansal açıdan istikrarın korunmasını, kulüplerin yükümlülüklerini eksiksiz yerine getirmesini, kaynak dağılımını dengelemesini ve kulüplerdeki finansal performansını artırmayı amaçlamaktadır(Akşar,2005:66). FFP kriterlerinin genel çerçevesinde ifade edilen kurallarda ise; kulüp yöneticilerinin bireysel varlıklarından harcama yapamayacağı, transfer işleminden elde edilen gelirden fazlasının harcama konusu olamayacağı, bütçenin denk olacağı, gelir ve giderlerde başabaş noktası kuralına uyulacağı, yükümlülüklerin vadesinde ödeneceği, eksi bakiyeye müsaade edilmeyeceğibelirtilmiştir(Akşar,2013:59). Dolayısıyla, FFP kriterleri, mali disiplini sağlamanın yanında, kulüp bünyesindeki faaliyetlerin verimliliğini, operasyonel ve kontrol süreçlerinin iyileştirilmesini, kulüplerin sağlıklı ve güçlü bir yapıya kavuşturulmasını ve finansal sürdürülebilirliği amaçlayan kurallardan oluşmaktadır(Deloitte,2018:101). 
FFP kriterlerinin uygulanmasında en önemli konu, kulüp altyapısındaki tüm ana süreçlerin bu kurallara uygun olarak tasarlanmasıdır. Spor kulübündeki faaliyetlerin, ortak, merkezi ve bütünleşik bir veri tabanı üzerinden izlenmesi, faaliyetlerin daha sıkı kontrol edilmesi, mali disiplinin korunması ancak uygun bilgi teknolojisi altyapısıyla mümkündür. $\mathrm{Bu}$ anlamda, kulüpteki finansal raporlama sisteminin daha doğru ve güvenilir olması ve profesyonel sportif hizmetlerin daha şeffaf ve sağliklı yürütülmesi güçlü bir teknolojik üstünlüğü de beraberinde getirecektir. Ayrıca, halka açık spor kulüplerinin finansal raporlama sistemimin FFP kriterlerine uygun olarak yürütülmesi, muhasebe standartlarına uygun kayıt ve raporlama ile mümkündür. Dolayısıyla, spor kulüplerindeki finansal raporlama sisteminin muhasebe standartlarına uygun olarakyapılması,hem profesyonellik hem de kurumsallık açısından kulüplerin istenilen seviyeye ulaşmasına yardımcı olacaktır. Bu konuyla ilgili örnekler ilerleyen başlıkta ele alınacaktır.

\section{TMS ÇERÇEVESINDE SPOR KULÜPLERINDEKİ IŞLEMLERIN MUHASEBELEŞTIRILMESİ VE SUNUMU}

Spor kulüplerinin şirketleşmesi, halka açılmaları ve paylarının borsada işlem görmeye başlamasıyla birlikte, kulüp bünyesinde gerçekleşen bütün işlemler dernekler kanunundan farklı olarak TMS ve SPK nezdindeki ilgili mevzuat ve düzenlemelere göre yapılır hale gelmiştir. Bu kapsamda, finansal raporların doğru, güvenilir ve karşılaştırılabilir hale gelmesi, mali nitelikli işlemlerin gerçeğe uygun şekilde raporlanması ve sunulması spor kulüplerinin en önemli konularından biri haline gelmiştir. Kamuoyuna hesap verme yükümlülüğü bulunan kulüplerdeki bütün işlemlerin, TMS hükümlerine uygun olarak raporlanması ve gerekli açıklamalarla desteklenmesi ise bu düzenlemelerin bir gereği konumundadır. Aşağıda konuyla ilgili örnekler TMS hükümleri esas alınarak incelenecek olup hesap isimleri konusunda Tek Düzen Hesap Planı çerçevesinde uygulamada yerleşik isimlere de yer verilecektir.

\subsection{Sporcuların Sözleşme, Lisans ve Transfer İşlemlerinin Muhasebeleștirilmesi}

Profesyonel sporcuların lisans alması, kulüp adına tescil edilebilmesi ve kulüplerle sözleşme yapabilmesi için, UEFA kulüp lisanslama için mali kriterleri doğrultusunda hazırlanan Profesyonel Futbolcuların Statüsü ve Transferleri Talimatı'nın 14.maddesine göre imzalanan sözleşmesini federasyona sunmuş olması gerekmektedir. Bu kapsamda, profesyonel sporcular sözleşme yapılmaksızın herhangi bir sportif faaliyette bulunamayacaktır(Soysal,2010). Bunun yanında sporcunun kulüp bünyesinde çalıştırılması veya başka bir kulübe transfer edilmesi aynı talimat doğrultusunda düzenlenmiş bulunmaktadır.

Sporcu sözleşmelerinin muhasebeleştirme işlemlerindekiuygulamalarda gerek raporlama gerekse açıklama detaylarında benzerlikler görülmektedir. Sporcu sözleşmeleri ve bununla ilgili katlanılan maliyetleri dikkate aldı̆̆ımızda ilk muhasebeleştirme esnasında uygulanan yöntem, maliyet değeri ile kayda alınması ve sınırlı süreli bu sözleşme bedelinin maddi olmayan duran varlıklar grubunda "Haklar" hesabında izlenmesi ve aktifleştirilmesidir. Burada dikkat edilmesi gereken bir husus, sözleşmenin üçünü taraflara yapılacak tutarlar üzerinden olması, belirli bir sürede sona erecek olması ve altyapıdan yetişen sporcuların sözleşme olmaksızın doğrudan kayıtlara alınmamasıdır. Dolayısıyla, mevcut sözleşme çerçevesinde süre uzatımı gibi durumlarda ortaya çıkan değişiklikler aynı sözleşme ile birleştirilmemeli, ayrı bir sözleşme olarak dikkate alınmalı ve ayrıca aktifleştirilmelidir. 
Nitekim TMS 38 Maddi Olmayan Duran Varlıklar Standard1, konuyu; belirlene bilirlik(md.11), kontrol(md.13) ve gelecekteki ekonomik yararlar(md.17) olarak ele almış ve muhasebeleştirme ve ölçüm esasında ilk kayda almada "Bir maddi olmayan duran varlık ilk muhasebeleştirilmesi sırasında maliyet bedeliyle ölçülür” (md.24) hükmünü getirmiştir.

Standart, dönem sonu işlemlerindemaliyet yöntemi(md.74) ya da yeniden değerleme yöntemine(md.75) göre değer düşüklüğü zararları düşülmüş olarak izlenmesi gerektiğini ifade etmiştir. Ayrıca menajerlik ücreti sporcunun kulüpte oynamaya hazır hale getirilmesine yönelik olduğu ve doğrudan sporcu ile ilişkilendirildiği için toplam maliyete dâhil edilmesi ve aktifleştirilmesi doğru bir yaklaşım olacaktır(Yazarkan,2016).Bunun yanında, sözleşmeler aktifleştirildikten sonra yapılan harcamalar varsa bunlar da toplam değere ilave edilmeli ve itfa edilmelidir(Pavlovic,2014:80). Ancak süre uzatımı gibi bir durum olması halinde, kalan değer ile yeni belirlenen değer karşılaştırılmalı ve yeni bir itfa süresi belirlenmelidir. Burada aktifleştirilen değer, lisanstan kaynaklı bir değerdir, sporcuya ait bir değer değildir ve sözleşme uyarınca bu hakkın kullanım yetkisi spor kulübüne geçmiş olmaktadır(Martin ve Johan, 2014,44).

Sporcu sözleşmelerinin döviz cinsinden olması durumunda konu; “...yabancı para bir işlem, yabancı para biriminde gerçekleştirilmiş ya da ödemenin yabancı para biriminde gerçekleştirilmesini gerektiren bir işlem olup, yabancı para işlemi ilk muhasebeleştirme sırasında; yabancı para birimindeki tutara, geçerli para birimi ile işlem tarihindeki yabancı para birimi arasındaki geçerli kur uygulanarak, geçerli para biriminden kaydedilir" hükmü geçerli olacaktır(TMS 21:md.20-21). İzleyen raporlama dönemi sonunda ise; "yabancı para parasal kalemler kapanış kurundan çevrilir(md.23) ve kur farkları oluştukları dönemde kâr veya zararda muhasebeleştirilir"'(md.28). Dolayısıyla, sporcu sözleşmelerinde ödemelerin taksitli yapılması, dönem sonunda döviz kuru çevrim işlemlerinin yapılmasını gerektirecektir ve bu durum kambiyo karı ya da zararının oluşmasına etki edecektir.

Örnek: Kulüp, yeni transfer ettiği sporcu ile,01.01.2019 tarihinde, 3 yıllığına ve toplam 30.000 TL tutarlı bir sözleşme yapmıştır. Tutara menajerlik ücreti dahil olup, ödeme üç eşit taksitte, ilk ödeme ise sözleşme imzalandığı esnasında yapılacaktır. Bu işleme ilişkin muhasebe kaydı aşağıdaki gibidir:

\begin{tabular}{|ll|}
\hline HAKLAR & 01.01 .2019 \\
Transfer Bedeli & \\
Menajerlik Ücreti & \\
& BANKALAR \\
Lisans Sözleşmesi Kaydı & GIDER TAHAKKUKLARI \\
\hline
\end{tabular}

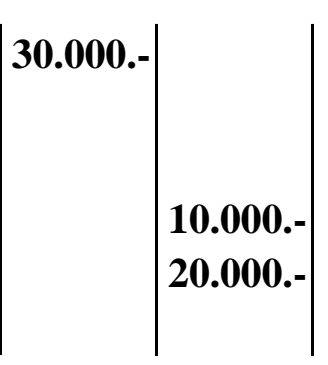

TMS 36 Varlıklarda Değer Düşüklüğü standardına göre, sınırlı ömre sahip varlıklar faydalı ömrü süresince itfa edilmelidir. İlk kayıt sonrası değerlemede seçilecek maliyet yönteminde; maliyet değeri üzerinden birikmiş itfa payı ve var ise değer düşüklüğü zararı düşüldükten sonraki tutarıyla izlenir. Yeniden değerleme yönteminde ise, bu değer düşüklüğüne ilişkin önemli göstergenin ortaya çıkması halinde her yıl yapılacak değer 
düşüklüğü testi, değer azalışının olup olmadığının tespitine olanak verecektir. İtfa edilmiş değerleriyle izlenen bu lisanslarda önemli bir konu kalıntı değerin tespitidir.

TMS 38 kalıntı değerin dikkate alınmasını belirli şartlarda gerekli görürken, bazı hallerde yok kabul etmekte ve sifir kabul etmektedir(md.100). Bu bilgiden hareketle, sözleşmesi biten sporcunun transfer işleminden, mevcut kulübün gelir elde etmesi kesin olmadığ1 ve üçüncü şahıslar nezdinde transfer ve lisans satış garantisi olmadığ 1 için sporcunun tüm maliyetlerinin itfaya tabi tutulması ve kalıntı değerin sıfır kabul edilmesi doğru bir yaklaşım olacaktır(Morrow,2006:71). Dolayısıyla, "Bosman Kararı" olarak bilinen Avrupa Topluluğu Adalet Divanı tarafindan 1995 yılında verilen karardan sonraki süreçte, sözleşmesi biten sporcunun, bundan sonra herhangi bir bonservis bedeli olmaksızın istediği spor kulübüne gitmesinin yolu açılmış ve sadece sözleşme süresi içerisinde sözleşme bedelinin itfa edilmesine olanak tanınmıştır.

Örneğimizdeki sporcu sözleşmesinin maliyet bedeli ile değerlenen varlıklar için dönem sonunda yapılacak amortisman ayırma işlemi ise aşağıdaki gibi olacaktır:

31.12.2019

\section{HİZMET ÜRETIM MALIYYETI}

Sporcu Sözleşmeleri

Amortisman Kayd1

\section{BİRIKMİŞ AMORTISMANLAR (-)}

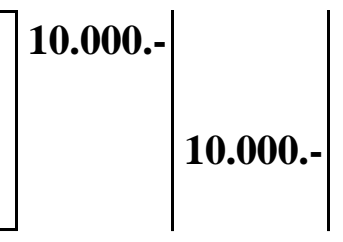

Yeniden değerleme yönteminin seçilmesi halinde ise; "Bir maddi olmayan duran varlık, ilk muhasebeleştirilmesinin ardından, yeniden değerleme tarihindeki gerçeğe uygun değerinden birikmiş itfa ve değer düşüklüğ̈̈ zararlarının tamamı düşüldükten sonra hesaplanan tutarı olan yeniden değerlenmiş tutarı üzerinden izlenir. Bu Standarda göre yeniden değerleme yapmak için, gerçeğe uygun değer, aktif bir piyasa ile ilişkilendirilmek suretiyle ölçülür. Yeniden değerleme işlemleri, raporlama dönemi sonunda ilgili aktifin defter değerinin gerçeğe uygun değerinden önemli ölçüde farklılık göstermemesi açısından düzenli olarak yapılır.(TMS38,md.75). Bir maddi olmayan duran varlı̆̆ın defter değerinin yeniden değerleme işlemi sonucunda artması durumunda, söz konusu artış diğer kapsaml gelirde muhasebeleştirilir ve yeniden değerleme fazlası adı altında özkaynakta biriktirilir. Ancak, anılan yeniden değerleme artışının, varsa daha önce aynı varlık için kâr veya zararda muhasebeleştirilen yeniden değerleme azalışını ortadan kaldıran kısmı, kâr veya zararda muhasebeleştirilir.(TMS38,md.85). Standartlardaki bu hükümler çerçevesinde, sporcu sözleşmelerinde, varlığın gerçeğe uygun değerinde meydana gelen artışlarda yapılacak kayıtaşağıdaki gibi olacaktır: 
31.12.2019

\begin{tabular}{ll} 
HAKLAR & \\
Sporcu X & MADDİ OLMAYAN DURAN VARLIK \\
Yeniden Değerleme Kaydı & YENIDEN DEĞERLEME ARTIŞLARI \\
\hline
\end{tabular}

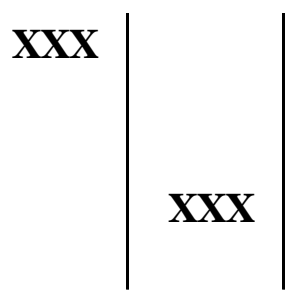

Sporcunun sakatlanması ve oyun dışı kalması halinde ise, TMS 36 gereği, maliyet bedeli üzerinden değer düşüklüğü hesaplanacak ve karşılık ayrılması gerekecektir. Örnekteki durumda;lisans sözleşmesi 30.000 TL olan sporcunun, içinde bulunulan dönemde sakatlanıp oyun dışı kalması nedeniyle kulüp tarafından hesaplanan 5.000 TL değer düşüklüğü zararı kaydı, dönem sonundaaşağıdaki gibi olacaktır:

\subsubsection{9}

KARŞILIK GIDERLERI

Değer Düşüklüğü Zararı

MODV DEĞER DÜŞÜKLÜĞÜ ZARAR KARŞILIKLARI

Değer Düşüklüğü Kayd1

Sporcularla ilgili katlanılan maliyetlerden olan transfer ücretlerinin yüksekliği ve diğer ödemeler ise günümüzde sporcu kiralamasını yaygınlaştırmıştır. Bu kiralamalarda, sporcunun lisansına sahip olan başka bir kulübe sezon ya da maç başı olmak üzere kira gideri ödenmektedir. Sporcuların sözleşme bitmeden önce başka bir kulübe satılmaları/kiralanmaları durumunda, sözleşmede yazılı tutarın üzerinde elde edilen gelir, kulüp için esas faaliyet geliri olarak kaydedilmeli ve Diğer Faaliyetlerden Çeşitli Gelir ve Kazançlar hesabında izlenmelidir. Ayrıca satışa konu edilen lisans bedelinin faydalı ömrü henüz tamamlandığından mevcut kulüp kayıtlarındaki Birikmiş Amortismanlar(-)hesabının da kapatılması gerekecektir. Örnekteki sporcunun, sözleşme bitimine bir y1l kala başka bir spor kulübüne 20.000 TL'ye satılması durumunda aşağıdaki kayıt yapılacaktır:

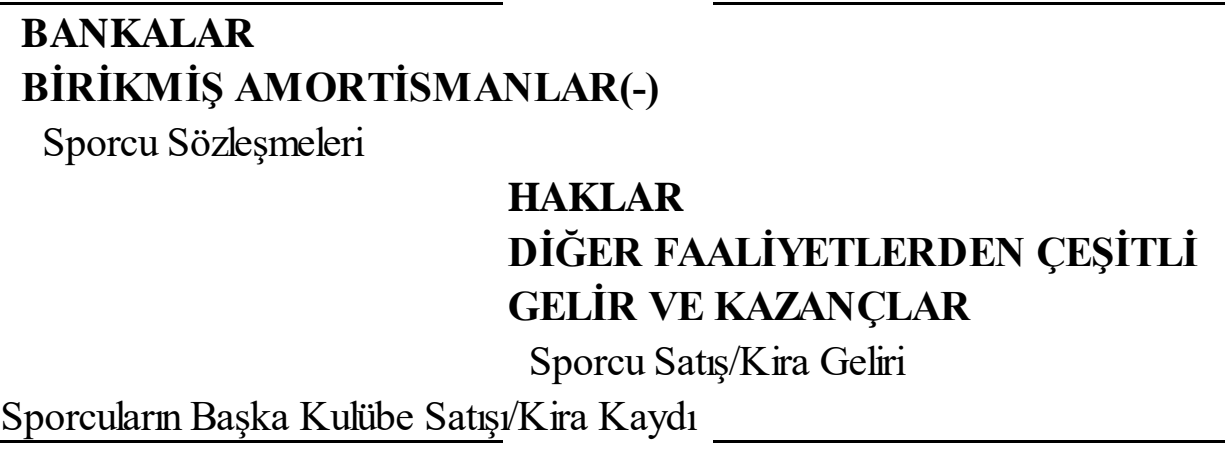




\subsection{Kulüp Maliyetve Giderlerin Muhasebeleştirilmesi}

Spor kulüplerinde altyapıdan yetiştirilen sporcular için katlanılan maliyetlerin aktifleştirilmesi önemli bir noktayı işaret etmektedir. Altyapıdan yetişen sporcular, kulüp bünyesinde çalışmalarını sürdürmektedirler ve kulübe olan maliyetlerinin izlenmesi yönetimin dikkat ettiği konular arasında yer almaktadır. Kulübün ilerleyen zamanlarda bu sporcularla yapacağ 1 lisans sözleşmesine kadar olan sürede katlanmış olduğu maliyetler dönem gideri olarak değerlendirilmeli ve sözleşme sonrasındaki dönemde maliyet bedeli ile aktifleştirilmelidir. Burada, maliyet bedelinin her bir sporcu için ayrıştırılması gerekliliği pratikte oldukça zor bir konudur. Ayrıca, altyapıdan gelen her sporcunun başarılı olma konusunda herhangi bir garantisi de bulunmamaktadır. Dolayısıyla, altyapıdan gelen sporcularla yapılan sözleşmelerde, o zamana kadarki sürede katlanılan maliyetler, varsa bunların yetiştirilmesi için kullanılan kredilerin ve faiz giderlerinin kayıtlara alınması sporcular için gerçek değerin tespitinde önemli zorlukları barındırmaktadır çünkü öncesinde yapılan bütün bu ödemeler güncel piyasa değerinden oldukça farklı olacaktır, gerçeğe uygun değerin tespitini zorlaştıracaktır. Ancak, sözleşmeye kadar geçen süredeki maliyetlerin aktifleş̧irme işleminde dikkate alınması ve bilançoya sözleşme bedeliyle kaydedilmesi doğru bir yaklaşım olacaktır.

Altyapıdan yetiştirilen sporcularla ilgili standart hükmü; "Bazı durumlarda, işletmeye gelecekte ekonomik yararlar sağlamak amacıyla birtakım harcamalar yapllır, ancak söz konusu harcamalar sonucunda muhasebeleştirilebilecek herhangi bir maddi olmayan duran varlık veya diğer bir varlık elde edilmez veya oluşturulmaz. Mal alımının söz konusu olduğu durumlarda, bu tür harcamalar, işletmenin mallara erişim hakka doğduğu anda gider olarak muhasebeleştirilir."(TMS38,md.69) ş̧eklindedir. Bu nedenlerle, altyapıdan yetiştirilen sporcuların maliyet bedeliyle aktifleştirilmesinin zorluğu, barındırdığı önemli belirsizlikler, içinde bulunulan zamandaki piyasa değerinin farklllığı gibi faktörler hiç aktifleştirilmemesi ve bunun finansal tablolara etkisi ile ilgili tartışmaları beraberinde getirebilecektir. Kulüp içerisinde, altyapıdan yetiştirilen sporcularla ilgili olarak, Yapılmakta Olan Maddi Olmayan Duran Varlık Yatırım Maliyetlerihesabında izlenen tutarlar, lisans sözleşmesi yapılan kadar bu hesapta takip edilebilir ancak altyapıdan yetişen sporcunun lisans sözleşmesi yapması halinde burada izlenen tutarlar İşletme İçinde Oluşturulmuş Maddi Olmayan Duran Varlıklar(MODV)hesabında izlenebilir. "Geliştirme safhasında olan maddi olmayan duran varlıklardan kullanıma hazır hale gelenler "Geliştirme Maliyetleri" hesabı karşılığında bu hesaba aktarılır. Bu hesapta yer alan maddi olmayan duran varlıklar açılacak alt hesaplarla sınıflar itibarıyla izlenebilir”'(KGK,2019:14). Buna ilişkin örnek aşağıdadır.

\begin{tabular}{|c|}
\hline YAPILMAKTA OLAN YATIRIMLAR \\
Altyapıda Yetiştirilen Sporcular \\
YAPILMAKTA OLAN YATIRIMLAR \\
MALIYET YANSITMA HS. \\
Altyapı Yetiştirme Maliyetleri \\
Altyapıdan Yetiştirilen Sporcu Kaydı
\end{tabular}

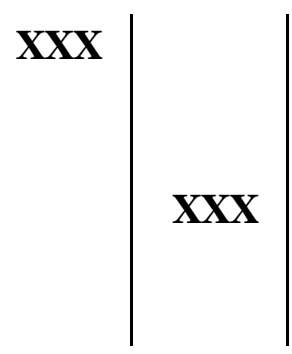




\section{../../...}

\begin{tabular}{|c|}
\hline ISSLETME İÇî́NDE OLUŞTURULAN MODV \\
Altyapıdan Yetişen Sporcular \\
YAPILMAKTA OLAN YATIRIMLAR \\
Altyapıda Yetiştirilen Sporcular \\
Altyapıdan Yetiştirilen Sporcunun Aktifleştirimesi Kaydı \\
\hline
\end{tabular}

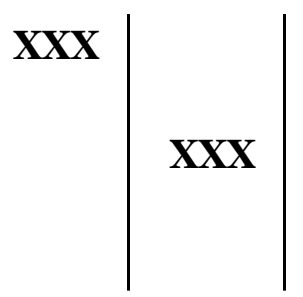

Spor kulüplerinin faaliyetlerini gerçekleştirirken katlanmış olduğu önemli giderler mevcuttur ve bunların en başta gelenlerinden biri müsabakaların yapıldığı stadyumlar için yapılan büyük miktarlardaki kira ödemeleridir. Bu kiralamalar belirli bir yıla kadar olabileceği gibi sezonluk da olabilmektedir. Genel Yönetim Giderleri altında muhasebeleştirilen bu giderler:(a) İşletmenin varliğl normal faaliyet döngüsü içinde gerçekleştirmeyi beklemesi ya da satmayı ve tüketmeyi amaçlaması, (b) İşletmenin varlığ esas olarak ticari amaçla elde tutması, (c) İşletmenin varliğı raporlama döneminden sonraki on iki ay içinde gerçekleştirmeyi beklemesi veya (d) Raporlama döneminden sonraki en az on iki ay içinde bir yükümlülüğ̈̈ yerine getirmek amacıyla kullanılmasının ya da takas edilmesinin sinırlandırllmamış olması koşuluyla, varlığın nakit veya nakit benzeri olması halinde dönen varlı, bunların dışındaki diğer tüm varlıklarını duran varlık olarak sinıflandırır.(TMS1, md.66-67). Ayrıca dönemsellik ilkesi gereğince raporlanma yapılırken, dönem sonunda tahakkuk esasına göre dönem ayırıcı hesaplar kullanılmalıdır. Bununla ilgili örnekaşağıdadır:

\begin{tabular}{|l|}
\hline GENEL YÖNETIM GIDERLERİ \\
Stadyum Kirası \\
PEŞiN ÖDENMIŞ GIDERLER \\
GELECEK YILLARA AIT GIDERLER \\
Stadyum Kiralama Kaydı \\
BANKALAR
\end{tabular}

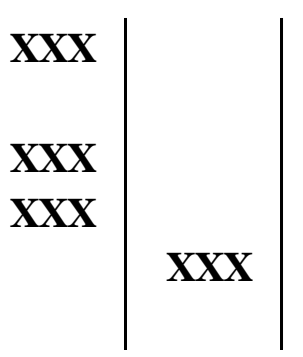

Spor kulüplerinin bir sezondaki en büyük maliyetlerinden diğeri teknik kadro maliyetleridir. Bu teknik kadro maliyetlerine, transferler, bonservisler, antrenör ve sporculara yapılan ödemeler, başarı performansına göre verilen ödüller ve galibiyet primleri dahil olmaktadır. Kulübün sporculara galibiyet primi dağıtması durumunda yapılacak kayıt ise aşağıdaki gibi olacaktır:

\section{ESAS FAALIYETLERDEN ÇEŞITLII GIDER VE ZARARLAR}

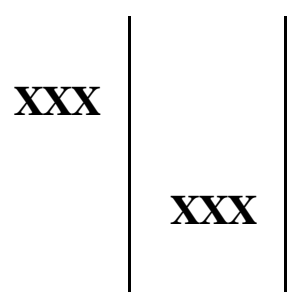


Spor müsabakalarında, hakem ve gözlemcilerin giderleri, biletlerin baskı ve dağııımına ilişkin harcamalar, gişe giderleri, hasarların giderilmesi için katlanılan giderler ve ses/video çekimlerine yapılan ödemeler maçlarda karşılaşılan önemli giderlerdendir. Bunlar da, aynı şekilde, kulüp açısından Esas Faaliyetlerden Diğer Çeşitli Gider ve Zararlar(-) şeklinde muhasebeleştirilmelidir.

\subsection{Ticari Gelirler ile Yayın Gelirlerinin Muhasebeleştirilmesi}

Spor kulüpleri katlanmış oldukları giderleri karşılayabilmek için çeşitli gelir kaynaklarına sahiptirler. Bunlar ticari gelirler olabileceği gibi maç günü gelirleri, stada ait büfelerdeki satış gelirleri,yayın hakkı gelirleri, sponsorluk ve reklam gelirleri, logolu ürün satış ve bayilik gelirleri de olabilmektedir. TMS 15 Hasılatstandardı göre, "İ̧sletme, devredilecek mal veya hizmetler için yapılacak ödeme koşullarını tanımlayabilmektedir.(md.9),hükmü gereği, ilgili sözleşmelerin ödeme tutarları esas alınmak suretiyle tahakkuk esasına göre muhasebeleştirilmektedirler. Hizmet gelirleri ise profesyonel kulüplerin resmi ve özel müsabakalarından elde ettikleri naklen yayın geliri, UEFA performans gelirlerinden meydana gelmektedir. Bütün bu gelirler, yapılan sözleşmeler çerçevesinde elde edilmekte olup hak edildikleri dönemde tahakkuk esasına göre, döneme ait olanlar ise esas faaliyet geliri olarak muhasebeleştirilmelidir.

Kulüplerin önemli gelir kaynaklarından birisi havuz yayın hakkı gelirleridir. Liglerde yapılan karşılaşmalardan elde edilen gelirler federasyona ödenen kısmı dışında kalan tutar spor kulübüne bırakılmaktadır. Bu konuda TFF tarafindan yürürlüğe koyulan havuz sistemi esasları çerçevesinde süper lig yayın gelirleri kulüpler arasında performans bazlı bir sisteme göre dağıtılmaktadır.Bu gelirlerde dikkat edilmesi gereken husus, TFF tarafindan kulübe ödenmesi gereken tutarın henüz ödenmeyenlerinin tahakkuk ettirilmesidir. Burada gelirin kazanılması ile kulüplere dağıtımı arasında dönemsel bir fark olabilmektedir. Bu durumda mali tablosu çıkarılan dönemler itibariyle, hak kazanıldığı halde TFF tarafindan ödenmeyen tutarların olup olmadığı araştırılması gerekmektedir. Eğer henüz ödenmeyen kısımlar mevcutsa bu tutarlar tahakkuk ettirilmelidir.

UEFA tarafindan kulübün payına düşen havuz geliri ise, UEFA'nın yayınlardan, reklamlardan ve sponsor gelirlerinden oluşan "UEFA Yayın Havuzu"ndan Şampiyonlar Ligi'ne gitmeyi hak eden ve UEFA Kupası, Süper Kupa gibi müsabakalarda finale yükselebilecek olan kulüplere belirli kriterler çerçevesinde dağıtımı yapılan payı ifade etmektedir. UEFA naklen yayın havuz gelirleri, UEFA tarafindan yayın hakkı verilen ulusal kuruluşun UEFA naklen yayın havuzundaki katkısının büyüklüğüne, müsabakalara katılan spor kulübü sayısına, kulüplerin geçmiş sezonda ulusal ligdeki başarısına, Şampiyonlar Ligi'ndeki performansa ve diğer spor kulüplerinin performans değerlendirmelerine göre dağttılmaktadır(İkiz,2010:5). TFF tarafından kulübün payına düşen havuz haklarından yayın gelirine ilişkin örnek aşağıdadır: 


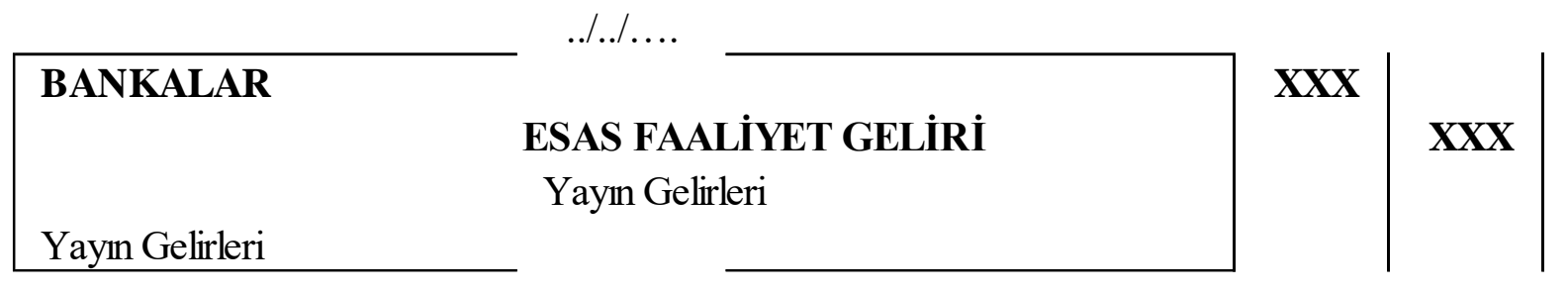

Spor kulüplerinin en önemli gelir kaynaklarından bir diğeri bilet satışlarıdır. Bilet satışlarında standartlar açısından dikkat edilmesi gereken husus, kombine bilet satı̧larında hasılatın, içinde bulunulan dönemde değil de biletin kullanıldığı döneme kaydedilecek olmasıdır. Bir diğer ifadeyle, TFRS15'de de ifade edildiği şekliyle, dönemsellik ilkesi gereğince, hasılatın tamamı lig döneminde yapılan müsabakalara eşit olarak dağıtılmalı ve dönemsel olarak dağıtılan bu tutarlar ilgili dönemde hasılat olarak kayda alınmalıdır. Bilet satışları döneme ait ise içinde bulunulan dönemde esas faaliyet geliri olarak kayda alınmalı ve alt hesaplarda detayı izlenmelidir. Buna ilişkin örnek ise aşağıdadır:

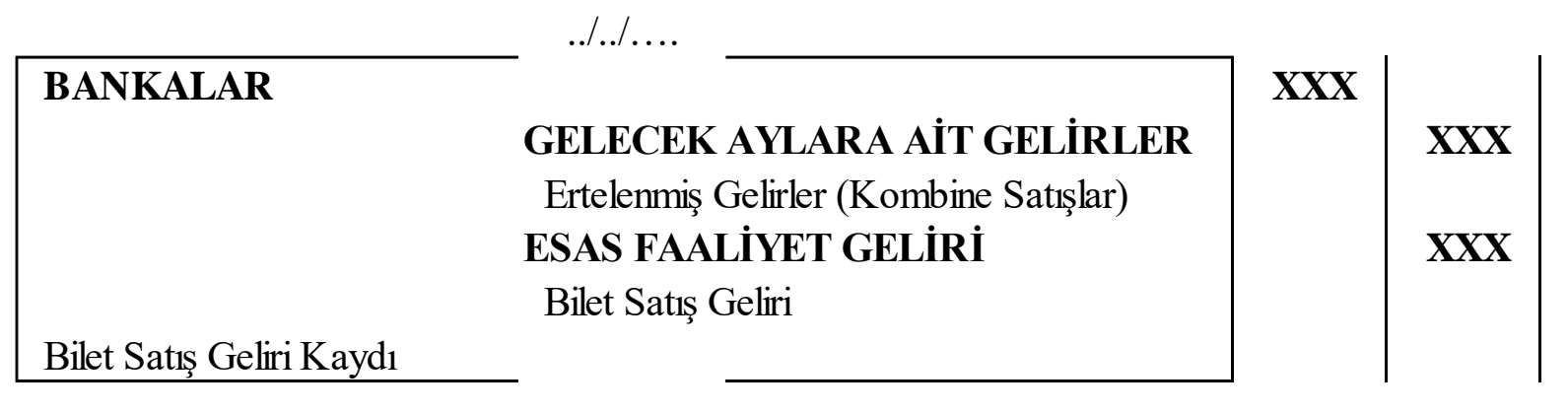

TFF'nin “Forma ve Reklam Talimatı"nda ifade edildiği üzere, müsabakalara katılmaya hak kazanansporcu ve görevlilerin spor kıyafetlerinde, sahada veya sahanın çevresindeki alanların üzerindeki gerek gerçek gerekse sanal olarak tasarlanan reklamlar bir diğer gelir kalemini oluşturmaktadır. Reklam gelirleri, kulüplerin mali tablolarında satış gelirleri olarak muhasebeleştirilmekte olup dipnotlarda satı̧̧ gelirlerinin altında detayına yer verilmesi gerekmektedir. Bu gelirlerin peşin tahsil edilen tutarından cari yıla yansıyan kısmı gelir yazılırken sonraki döneme kalan kısmı ise gelecek aylara ait gelirler altında muhasebeleştirilmektedir. Reklam gelirlerinin muhasebesinde önemli olan husus, reklam gelirinin ilişkili olduğu dönemin doğru tespit edilmesidir. Çünkü çoğu reklam gelir kaleminde birden fazla dönem için (sezon için) sözleşmeler yapılmaktadır. Bazı hallerde sürenin ya belirsiz veya bir maçlık olabilmesi durumuna göre, bu süre birden fazla hesap dönemini kapsıyor ise, bu gelirin ilgili olduğu dönemlere yayılması gerekmektedir.Halka açık spor kulüplerinin finansal tablolarında yer alan yayın, reklam, sponsorluk, isim hakkı gibi sözleşmeyle belirlenmiş bütün bu gelirlerin ilerleyen dönemlerle ilgili kısmının "Ertelenen Gelirler" olarak kayda alınması, diğer gelirlerin ise Gelir Tahakkuku olarak kaydedilmesi standartlara uygun bir yaklaşım olacaktır. Sponsorluk kapsamında sözleşme yapılması durumunda elde edilen bu gelirlere ilişkin örnek aşağıdadır: 
....$/ \ldots$

GELİR TAHAKKUKLARI

Sponsorluk Gelirleri

ESAS FAALIYET GELIRI

Sponsorluk Gelirleri

Sponsorluk Geliri Tahakkuk Kaydı

Spor kulüpleriyle ilgili mevzuat gereği, müsabakalarda kazanılan başarılarda verilen prim, ödül ve buna benzer ödemelerin yanında, gerek sporculara gerekse de rakip kulüplere kanunlara aykırı nitelikteki eylem ve davranışları nedeniyle verilen ceza ve tazminatlar spor kulüpleri açısından gelir niteliği taşımaktadır. Bu tür durumlarda elde edilen gelir hasılat olarak kayda alınmalı ancak dipnotlarda bilgi verilmelidir. Benzer şekilde, sporcuya verilen para cezaları da kulüp açısından gelir kaynağı olmaktadır.Buna ilişkin örnek aşağıdadır:

..$/ . / \ldots$

\begin{tabular}{|l|l|}
\hline BANKALAR & DÍĞER FAALIYETLERDEN ÇEŞITLİ \\
GELİR VE KAZANÇLAR \\
Ceza Gelirleri \\
Sporcuara Verilen Cezanın Gelir Kaydı
\end{tabular}

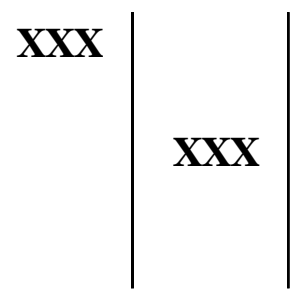

Spor kulüplerindeki üyelik sistemi Dernekler Kanunu md.60'da düzenlenmiş bir konu olup, kulübe ödenen aidatlar gelir niteliği taşımaktadır. Ayrıca, spor kulüplerine düzenli ödenen bu aidatlar, kulübe olan mensubiyeti ifade etmekte ve özellikle yeni kurulan kulüpler açısından, aidatların sürekliliği doğrudan faaliyetlerin devamlılığına katkı sağlamaktadır. Ancak, aidatlar düzenli bir ödemeyi ifade ederken bağış ve yardımlar düzenli bir ödemeyi ifade etmemektedir. Dolayısıyla, spor kulüpleri açısından önemli gelir kaynaklarından olan bağış ve yardımlar, süreklilik göstermemesi, düzenli olmaması gibi nedenlerle diğer gelirler altında muhasebeleştirilmelidir. Bu farklılığa ilişkin örnekler aşağıdadır:

..$/ . / \ldots$

BANKALAR

ESAS FAALIYET GELIRI

XXX

Üye Aidatları

Gecikme Zammı Geliri

Üye Aidat Kaydı, Aidat Ödemesi ve Gecikme Zammı Tahsilatı 


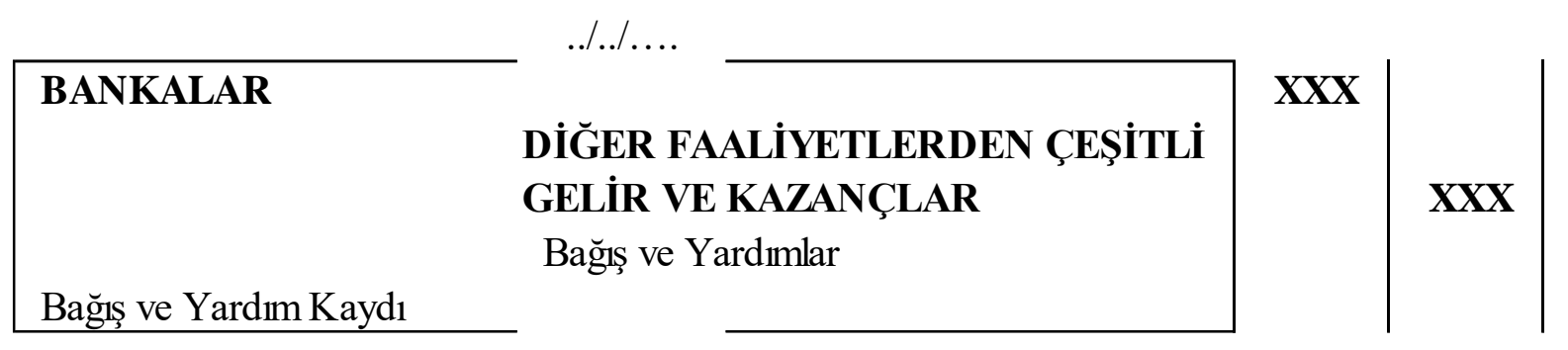

\section{SONUÇ}

Spor kulüplerinin geçmişten günümüze gösterdiği gelişme ve değişme, öncelikle kuruluş ve örgütlenme biçimlerinin değiştirmiş ve faaliyetlerinde çeşitliliği sağlamıştır. Yaşanan dönüşümün ve şirketleşmenin neticesinde, özellikle büyük kulüpler nezdinde halka açılma süreci başlamış ve yeni fon temini açısından önemli kazanımlar elde edilmiştir. Bunların yanında, şirketleşme ve halka açılmanın getirmiş olduğu imkanlar, hesap verme sorumluluğu anlamında bazı yükümlülükleri de beraberinde getirmiş̦ir. Kulüp bünyesinde yapılan tüm faaliyetler, gerçekleştirilen bütün işlemler başta UEFA mali kriterleri olmak üzere TFF açısından da takip edilmeye başlanmış ve bütün bu işlemlerin sonuçları kamuoyu ise paylaşı1ır olmuştur. Kamuoyu ile paylaşılan bilgilerin doğru, güvenilir ve şeffaf olması, hesap verilebilirliği beraberinde getirmiş ve kulüplerdeki işlemlerin muhasebeleştirme esasları uluslararası standartlarına daha bir uygun şekilde yapılmaya başlanmıştır.

Spor kulüplerinin dernek yapısı ile şirket tarafinın devam etmesi, muhasebeleştirme açısından bazı farklılıkları ve problemleri beraberinde getirmektedir ve bu durum mevcut ikili muhasebe sistemiyle ihtiyaçlara cevap verememektedir. Özellikle, ilişkili taraflar arasında yapılan işlemleri ele aldığımızda, gerçekleştirilen işlemlerin yoğunluğu ve parasal büyüklüğü muhasebeleştirme ilkeleri açısından ilave bilgilerin sunulmasını gerektirmektedir. Ancak, ülkemizde halka açı spor kulüplerinin mali tablolarındaki ilişkili taraf açılamaları ve dipnotlarına baktığımızda bu konuda detaylı bilgilerin yer almadığı görülmektedir. Bunların yanında, muhasebe standartları açısından ele alınan konulara bakıldığında, mevcut uygulamalarda standartlara tam anlamıyla uyum sağlanamamıştır. Bütün bu gelişmeler neticesinde, spor kulüplerindeki finansal raporlamada, yapılan işlem ve kayıtlarda muhasebe standartları açısından farklılıklar ortaya çıkmaktadır. Bu farklılıkların ortaya çıkarılarak çözümlerin üretilmesi ve daha doğru, güvenilir raporlama yapılması yerleşik uygulamalarda bazı değişiklikleri gerektirmektedir. Özellikle kullanılan hesap veya alt hesaplarda yapılacak açıklama ve dipnotlar, muhasebe standartları açısından farklı hesapların kullanılmasını beraberinde getirmektedir. Dolayısıyla, spor kulüplerinin başta UEFA mali kriterleri olmak üzere küresel anlamda rakiplerini birlikte ele aldığımızda, uluslararası muhasebe standartlarına uygun bir muhasebe sistemi geliştirmeleri, mevcut muhasebe sistemlerini buna uygun hale getirmeleri kaçınılmaz bir ihtiyaç halini almıştır. Bu kapsamda, TMS çerçevesinde yapılacak muhasebeleştirme işlemleri spor kulüplerindeki finansal raporlama sistemini geliştirecek ve kulüp bünyesinde gerçekleştirilen işlemler UEFA mali kriterlerine daha uygun hale gelecektir. 


\section{KAYNAKLAR}

Akşar, Tuğrul (2005), Endüstriyel Futbol. Literatür Yayınları, İstanbul, ss.41-42

Akşar, Tuğrul(2013), Krizdeki Futbol, 1. Baskı, Literatür Yayınları, İstanbul, ss.59-60

Aydın, AliDursun -Turgut, Murat - Bayırlı, Rıdvan (2007), "Spor Kulüplerinin Halka Açılmasının Türkiye'de Uygulanan Modeller Açısından İncelenmesi”. Ticaret ve Turizm Eğitim Fakültesi Dergisi, Sayı, 59 ss.70-94

Deloitte Sports Business Group, (2018),https://www2.deloitte.com/uk/en/pages/sportsbusiness-group/topics/sports-business-group.html. (20.05.2019)

Devecioğlu, Sebahattin -Çoban, Bilal - Karakaya, Yunus Emre - Karataş, Özgür (2012), “Türkiye'de Spor Kulüplerinin Şirketleşmeye Yönelimlerinin Değerlendirilmesi”. SPORMETRE Beden Eğitimi ve Spor Bilimleri Dergisi, Say1 10, ss.22-46

İkiz,

$$
\text { Mete. }
$$

Endüstri

olarak

FUTBOL.http://www.futbolekonomi.com/index.php/haberler-

makaleler/yonetim/121-mete-ikiz/363-bir-enduestri-olarak-futbol.html (20.05.2019)

KGK (2019). Finansal Raporlama Standartlarına Uygun Hesap Planı Taslağ1, http://kgk.gov.tr/ContentAssingmentDetail/2531/Finansal-Raporlama-

Standartlarına-Uygun-Hesap-Planı-Taslağ1, ss.47-59 (20.05.2019)

Martin, Bengtsson., veJohan, Wallström (2014), Accounting andDisclosure of Football Player Registrations: Do TheyPresent A True andFairView of the Financial Statements? Master'sthesis, Jönköping International Business School, JönköpingUniversity.pp.101-103

Morrow, Stephen (2006), "Impression Management in Football Club Financial Reporting", International Journal of Sports Finance, May, pp.78-104

Pavlovic, Vladan -Mijatovic, Predrag - Milacic,, Ljubisa (2014), "Controversiesaboutthe Accounting Treatment of Transfer Fee in the Football Industry." Management JournalforTheoryandPractice Management vol, 70, pp.110-135

Soysal, Tamer (2010), "Kulüp ile Profesyonel Futbolcu Arasındaki Sözleşmeler ve Sözleşmelerden Doğan İhtilaflarda Yarg1 Yeri”, Adalet Dergisi, Sayı 36, Ocak, ss.109-133

Sultanoğlu, Banu (2008), Hisseleri Halka Arz Edilen Türk Futbol Kulüplerinin Mali Tablolarının Türkiye Muhasebe Standartları Çerçevesinde İncelenmesi. (Yayımlanmamış Yüksek Lisans Tezi)Başkent Üniversitesi, Ankara, ss.125126 
TFF (2016), Türkiye Futbol Federasyonu Profesyonel Futbolcuların Statüsü ve Transferleri Talimat1, http://www.tff.org/Resources/TFF/Documents/TALIMATLAR/ProfesyonelFutbolcularin-Statusu-ve-Transferleri-Talimati.pdf. (20.05.2019)

TKYD (2009). Kurumsal Yönetim İlkeleri Işığında Türk Futbol Kulüpleri Yönetim Rehberi, Türkiye Kurumsal Yönetim Derneği Yayınları, ISBN 978-9944-70240-9, ss.38-41

TFRS 15 Müşteri Sözleşmelerinden Hasılat, 15/01/2019 tarihli ve 30656 sayılı Resmi Gazete

TMS1 Finansal Tabloların Sunuluşu, 24/05/2018 tarihli ve 30430 sayılı Resmi Gazete

TMS 21 Kur Değişiminin Etkileri, 15/01/2019 tarihli ve 30656 sayılı Resmi Gazete

TMS 24 İlişkili Taraf Açıklamaları, 18/09/2014 tarih ve 29123 sayılı Resmi Gazete

TMS 36 Varlıklarda Değer Düşüklügüü, 19/12/2017 tarih ve 30275 sayılı Resmi Gazete

TMS 38 Maddi Olmayan Duran Varlıklar, 15/01/2019 tarihli ve 30656 say1lı Resmi Gazete

UEFA (2012), UEFA Club Licensing and Finacial Fair Play Regulations, Edition, Europe,pp.101-107

Yazarkan, Hakan (2016), “Futbolcu Transfer/Bonservis Ücretlerinin TMS 38 Maddi Olmayan Duran Varlıklar Standardına Uygun Olarak Muhasebeleştirilmesi: Trabzonspor Örneği” İSMMMO Mali Çözüm Dergisi, Eylül Ekim, ss.70-96

Zeren, Feyyaz.,ve Gümüş, Fatih (2013), "Türk ve Yabanc1 Futbol Takımlarının Borsa Performansları Üzerine Bir Uygulama”. Çankırı Karatekin Üniversitesi İktisadi ve İdari Bilimler Fakültesi Dergisi, Sayı 3, ss.61-85 
